DOI: $10.2478 / \mathrm{v} 10282-012-0016-\mathrm{Z}$

\title{
Risk factors for gliomas. An extensive review
}

\author{
I.S. Florian ${ }^{1,2}$, G. Ungureanu ${ }^{1}$, C. Berce ${ }^{2}$ \\ ${ }^{1}$ Neurosurgery department,Cluj County Emergency Hospital \\ ${ }^{2}$ University of Medicine and Pharmacy Cluj
}

\begin{abstract}
Primary brain tumors consist are a heterogenic group of malignancies. Gliomas represent subtypes which include all tumors arising from glial cells. The risk factors for gliomas are until today unclear. The aim of this study was to summarize all possible connections between suspected risk factors and glial brain tumors.
\end{abstract}

\section{Introduction}

Primary brain tumors consist of a heterogenic group of malignancies. They have a relative small incidence when compared to other neoplasms. Their incidence varies according to different classification techniques used. According to Central Brain Tumor Registry of the United States (CBTRUS), in 2004-2008, their incidence in the US was 19.89 per 100,000 person-years (1). In the GLOBOCAN 2008 series published by the International Agency for Research on Cancer (IARC), brain tumors represented $1,9 \%$ of all cancers excluding nonmelanoma skin cancer $(2)^{\star}$. In the CBTRUS statistics, gliomas represent $30 \%$ of all primary CNS tumors and $80 \%$ of malignant ones (1).

Epidemiologic studies offer the possibility of understanding how a disease acts and who, when, where and why is exposed. They constitute the basis of understanding a disease and offer a chance on preventing and treating it. Epidemiologic studies concerning risk factors for gliomas have studied a multitude of possible elements, but their results until now have been mostly inconclusive. This is due to the small number of cases, to the heterogeneity of study designs, inconsistent approach to suspected risk factors. The goal of this review is to provide up to date knowledge concerning risk factors for gliomas and offer an overview of epidemiologic literature data available for glial tumors.

\section{Material and methods}

This article includes data from studies indexed by MEDLINE. We used the terms "brain tumors" or "gliomas" in combination with "epidemiology" or "risk factors". All articles, including reviews were covered. Articles published in the last five years were the first used when discussing a certain topic. When not available, older articles were included. All related abstracts to those initially used, were included. Three large epidemiological reviews were extensively used in order to create specific categories of risk factors (3-5). We have to mention that our search did not exclude articles cited by these reviews. We also have to state that we used data from experimental research in order to highlight certain facts. For every 
category of risk factors the terms (e.g. ionizing radiation) combined with "brain tumors" and "gliomas" were again searched for on Medline.

\section{Age and race}

Brain tumors affect more Caucasians than African or Asian descendants, this being true for all ages (4). The CBTRUS report indicates that whites are affected twice more frequent than blacks. Also, for all brain tumors, whites are affected more frequent than Hispanics. The incidence in Japan is half of that seen in Northern Europe (3).

Age-adjusted incidence tends to be higher in developed countries (4). For gliomas the peak incidence is situated in the 75-84 years interval (1). Age-adjusted incidence rates follow an ascending route, except the decrease in incidence in the $85+$ years (1).

\section{Gender, hormonal status, exogenous hormones and risk for developing gliomas.}

The fact that glioma incidence varies according to gender is now admitted by most studies. Given the fact that gliomas are less frequent in women, their age at diagnosis is higher, researchers have tried to study a possible link between female gender and gliomas (3). Data available from the CBTRUS shows a higher incidence in males than females (7.17/100 000 personyears vs. 5.07/100 000 person-years) (1). According to the same registry, gender is also important in survival, with females having longer survival rates for most types of tumors, except brain stem and pineal glands. While age alone should not disqualify patients from receiving complete treatment (6), a study found that women were older when diagnosed than men, and this was contraindication for treatment after surgery (7). Data from GLOBOCAN shows a higher incidence of new cases of brain tumors in men vs. women (127000 vs. 110000) (2). The number of deaths due to brain cancer is smaller in women vs. men (77000 vs. 97000) (2).

Experimental research, in which rats were transplanted with glial tumors, showed a slower rate growth in female rats, a longer survival for females and for the group estrogen treated group (both males and females) (8).

A review of current knowledge between hormonal status and gliomas, published in 2010, included 15 articles concerning gliomas. The final conclusion of the study is that female sex hormones are protective against gliomas and constitute risk factors for meningiomas (9). In contradiction, in the EPIC study no connection between feminine hormones and gliomas was found (10).

An older age at menarche was associated with a higher risk of gliomas in the NIHAARP Diet and Health Study (11). This conclusion was also drawn by researchers in other studies to (9). The NIH-AARP Diet and Health Study found no other link between female hormones and risk of gliomas (11). Ever being pregnant had a protective effect in one study (12). Some studies also found pregnancy to be a protective factor, while others found no relation between the two (9).

Research concerning the effect of exposure to exogenous hormones either by oral contraceptives or hormone replacement therapy and glioma risk had mixed results. Studies found a slightly higher risk (13), no influence $(10,14)$ or a protective role of this therapy (9). The later study combines conclusions from 15 studies, and majority of these studies 
sustain a protective role of exogenous hormone therapy against gliomas (9).

\section{Genetic risk factors - family aggregation, genetic syndromes and gene polymorphism}

The existence of a family member with a glioma, could represent a risk factor for the other members. Wrensch and all conducted a study were they showed that OR of a primary brain tumor (PBT) in family members of patients with PBT was 2.3 (95\% CI $=1.0-5.8 \quad$ (15).In a study of Malmer, the authors obtained similar results (16). The same author investigated if genetic factors or genetic ones were the cause of a higher incidence of brain tumors in families having one member already affected by the disease (17). The study revealed that standardized incidence ratio (SIR) among spouses of HGG patients was the same as in the general population, while SIR was 2.30 (95\% CI=1.66-3.11) for first degree relatives of patients diagnosed with HGG (17). Segregation analysis showed that family aggregation could explain only $5 \%$ of glioma cases, and that a recessive gene model fits in about $2 \%$ of all cases (18, 19). On the other hand, family aggregation wasn't confirmed by a study in Iceland (20).

There is strong evidence that some inherited genes influence the risk of developing a glioma. Some familial cancer syndromes are associated with brain tumors (4). The most important of these syndromes and the associated genes are LiFraumeni syndrome (TP53 mutations), type 1 and 2 neurofibromatosis (NF1 and NF2), tuberous sclerosis (TSC 1 and 2), retinoblastoma (RB1), and Turcot syndrome (APC and hMLH1/hPSM2 mutations) $(4,5)$.
Li-Fraumeni syndrome is characterized by a familial aggregation of tumors, with about $70 \%$ of cases carrying TP53 mutations (4). In the IARC database of LiFraumeni syndromes, 14\% of cases had a brain tumor, thus suggesting that familial gliomas could be related to p53 mutations (21). A study of 18 families with 2 or more cases of glioma, didn't show any connection to p53 mutations, infirming this hypothesis (22). It must be said that these families did not meet classic Li-Fraumeni criteria.

Neurofibromatosis type 1 is an autosomal dominant disorder characterized by cafe-au-lait spots and multiple neurofibromas and an increased incidence of diffuse astrocitomas, gliomblastomas, optic nerve gliomas (4). Neurofibromatosis type 2 is characterized by dysplastic and neoplastic lesions of the Schwann cells, meningeal and glial ones (4). About $80 \%$ of gliomas that occur in NF2 patients are tumors of the spinal cord and cauda equine (4).

Turcot syndrome is also an autosomal dominant disease, characterized by colonic adenomatous polyps and nervous system tumors, usually meduloblastomas (23).

Gene polymorphism has been intensively studied by researchers. Genes involved in DNA repair are probably the most studied category, because their role in preventing carcinogenesis (5). The methylation status of MGMT is not only involved in gliomagenesis but also it can predict tumor response to temozolamide treatment $(24,25)$. MGMT methylation together with microRNAs miR-21, miR181c, miR-195 are correlated to progression-free survival of GBM (26). MGMT F84L has been proven to be an important risk factor for gliomas (27). Individuals carrying wild-type genotypes of 
MGMT F84L and PARP1 A762VA, exposed to ionizing radiation have a much higher risk (27).A genotype, rs1760944 GG of APE1/Ref-1 promoter, involved both in DNA repair and redox activity, has been show to exert protective roles in glioblastomas (28).

A genetic variant of the CHAF1A gene is linked to an increased risk of disease (29). An AA or AC variant of the 8092 nucleotide of ERRC1 was 4.6 times more frequent in individuals with oligoastrocytoma (30). Another study showed that individuals homozygous for ERCC1 c8092a and ERCC2 k751q have an increasd risk for gliomas (31). Other subtypes of ERRC2 were also incriminated (g3). Chen identified that carriers of the two "CGT" haplotypes of Vascular Endothelial Growth Factor Receptor 2 (VEGFR 2) in a Chinese population had a $42 \%$ reduced risk of developing gliomas compared to noncariers (32). Other genetic variants of four genes rs4295627, a variant of CCDC26, rs4977756, a variant of CDKN2A and CDKN2B and rs6010620, a variant of RTEL1- were associated with glioma risk in a female population (33).

Tayrac and all identified a 4-gene signature (CHAF1B, PDLIM4, EDNRB, and HJURP), that strongly correlated with survival of HGG patients (34). But this thesis needs to be verified, since it has been proven that susceptibility variants published in glioma Genome-wide association studies (GWAS) are different between GBM, low grade astrocitomas or oligodendrogliomas (35).

\section{Exposure to ionizing radiation}

Ionizing radiation is the only carcinogenic agent that has been classified by IARC as being a certain risk factor for brain tumors. Studies have shown increased incidence of gliomas or PNETs in children that received prophylactic CNS irradiation for acute lymphoblastic leukemia (4). Various studies conducted to observe the effects of ionizing radiation on children treated for tinea capitis found that risk for gliomas increased immediately postradiation, being higher even after $\geq 30$ years, dose related, with no relation to gender or origin (4).

Different studies have analyzed effects of ionizing radiation after the exposure of the Japanese population to atomic bomb irradiation in Nagasaki and Hiroshima (3$5)$. They all found an increased incidence of all brain tumor types, including gliomas. One study from Hiroshima found a direct relation between risk and the distance from explosion epicenter (36).

\section{TABLE I}

Gene mutations, gene polymorphism, gene variants possibly implicated in glioma risk

\begin{tabular}{|l|l|c|}
\hline $\begin{array}{l}\text { Gene } \\
\text { mutations/gene } \\
\text { variants/genotypes }\end{array}$ & $\begin{array}{l}\text { Relation to } \\
\text { glioma risk }\end{array}$ & $\begin{array}{l}\text { No. of } \\
\text { Ref. }\end{array}$ \\
\hline Tp53 & $\begin{array}{l}\text { Increased or no } \\
\text { connection }\end{array}$ & $\begin{array}{l}21,22- \\
\text { mixed } \\
\text { results }\end{array}$ \\
\hline $\begin{array}{l}\text { MGMT } \\
\text { methylation }\end{array}$ & $\begin{array}{l}\text { Increased risk. } \\
\text { Predicts tumor } \\
\text { response to } \\
\text { temozolomide }\end{array}$ & 24,25 \\
\hline $\begin{array}{l}\text { PARP1 A762VA } \\
\text { genotype }\end{array}$ & Increased risk & 27 \\
\hline MGMT F84L & Increased risk & 27 \\
\hline $\begin{array}{l}\text { rs1760944 GG } \\
\text { genotype of } \\
\text { APE1/Ref-1 }\end{array}$ & Decreased risk & 28 \\
\hline CHAF1A - rs243356 & Increased risk & 29 \\
\hline $\begin{array}{l}\text { ATR (MIM 601215) } \\
\text { RPA3 (MIM } \\
\text { 179837) }\end{array}$ & $\begin{array}{l}\text { Could determine } \\
\text { genetic glioma } \\
\text { risk }\end{array}$ & 29 \\
\hline $\begin{array}{l}\text { ERCC1c8092a and } \\
\text { ERCC2 k751q }\end{array}$ & \begin{tabular}{l} 
Increased risk \\
\hline
\end{tabular} & 31 \\
\hline
\end{tabular}




\begin{tabular}{|l|l|c|}
\hline $\begin{array}{l}\text { homozygous } \\
\text { individual }\end{array}$ & & \\
\hline $\begin{array}{l}\text { CGT haplotypes of } \\
\text { VEGFR 2 }\end{array}$ & Increased risk & 32 \\
\hline \multicolumn{1}{|c|}{ The effect of medical exposure to } \\
\hline
\end{tabular}
ionizing radiation is yet to be clarified. Various studies assessed effect of either occupational exposure to ionizing radiation by technicians, radiologists or low-dose irradiation for diagnostic procedures- dental X-rays, head and neck X-rays, or CT of those areas (37). An INTERPHONE study found an insignificant increased risk for meningiomas or acoustic neuromas, but an inexplicable statistically significant lower risk for gliomas after any kind of medical exposure (37). Another study found an increased risk in a population that underwent $\geq 3 \mathrm{CTs}$, but only in those with a family history of cancer (38).

\section{Electromagnetic fields and use of mobile phones}

Probably the most important debate our days, concerning risk factors for malignant brain tumors, lies in the use of mobile phones. Several authors and institutions have conducted multiple studies that frequently show mixed results, and, moreover, results from one study are often contested by others conducting research in the same domain.

One of the most active organizations that published studies regarding the use of mobile phones is the Interphone Group that functions under the Auspices of IARC. Their international study comprised 2708 glioma and 2409 meningioma cases, from 13 countries (39). The authors found no link between either glioma or meningioma risk and the use of mobile phones, even after 10 years of usage. The Interphone study found only a higher risk for gliomas in the temporal lobe, and for those subjects that reported repeated use on the same side, but the CI varied in very large limits. The OR was 0.81 (95\% CI 0.70-0.94) in the regular mobile phone users group-defined by the authors as at least one call per week for more than six months. The OR was 1.40 (95\% CI 1.03-1.89) in the group that stated they used mobile phones more than $1640 \mathrm{~h}$. But the authors of the study argued that values for mobile phone use in this group, was very unlikely.

The results of the Interphone study were extensively contradicted. In an article from 2008, by Hardell and all (40) suggest that the results of the Interphone study are largely affected by bias, so that results could not be considered valid. Conclusions from the Swedish team of the Interphone Group that concluded that no relation exists between mobile phone use and risk of developing gliomas (41) were challenged by several researchers (42-44). Hardell conducted several studies were the researchers found a link between mobile phones and risk for developing severall types of tumors, including gliomas(45-48). In one study they found an increased risk for developing gliomas in people that used mobile phones for more than 10 years $(\mathrm{OR}=2.7,95 \%$ CI 1.9-3.7), this risk being even higher in those who started to use mobile phones before the age of 20 $(\mathrm{OR}=4.9, \mathrm{CI}=2.2-11)(45)$. Another study of the same author found a higher risk $(\mathrm{OR}=3.4$, 95\% CI 1.6-7.1) for those who used mobile phones for more than 2000 hours (46). A latency period of more than 10 years was a risk factor for developing gliomas $(\mathrm{OR}=2.0,95 \% \mathrm{CI} 1.2-3.4)$, even in a meta-analysis were results were compared with 16 other studies (49).

Results from five countries in the Interphone group, showed a higher 
incidence of gliomas in people that had a higher exposure to radio frequency fields (RF) from mobile phones $(\mathrm{OR}=1.91,95 \%$ CI 1.05-3.47)(50).

The conclusions of a long-term Danish cohort study published in 2011, was that no link exists between mobile phones and malignant brain tumors (51). This research updates information from a 2006 study (52), which in turn is an update of a study started in 2001 (53). The results of these particular analysis were contested, partially for its design and extensive bias possibilities, and partially because the financing was done in part by companies that were involved in mobile telecommunications (54-56).

In 2011, 30 scientists met at IARC, with the goal of establishing the impact that RF electromagnetic fields had on carcinogenesis. During that meeting, they established that RF magnetic fields are a potential risk factor for developing gliomas in humans (57). Their conclusions were based mainly on two studies, cited in this paper, one being the Interphone study and the other the study of Hardell and all.

The conclusions of the IARC group were compared by Little and all with the effect of RF magnetic fields on glioma risk in the US population, based on 12 registries of the SEER database (58). The conclusion was that the US data, could be compatible with the information obtained in the Interphone study (moderate risk when mobile phones are excessively used) but in contradiction with the results of Hardell's study.

Finally we can say that the debate surrounding the influence of mobile phones on the risk of developing glial tumors is far from being over. In 2009, in a review of available data (59), Kundi stated that four epidemiological aspects should be taken into account when analyzing this subject: temporal relation (the exact time when a brain tumor appeared), association (assessed as possible counterarguments for a possible relation), environmental factors (risk factors that could coexist with mobile phone usage) and finally population equivalence (both cases and controls should come from the same type of population). It is almost impossible for a case-control study, and most studies so far have been done using this approach, to follow these guidelines. A final conclusion on mobile phones-glioma risk relation will come probably, only when researchers will create a new model for a possible study.

\section{Lifestyle factors}

There is still little evidence of an association between any lifestyle factors and an elevated risk for malignant gliomas. Although certain factors like alcohol, diet, smoking have proven to be in relation to certain types of tumors (colonic, rectal, breast, lung) studies up to day were unable to identify any relevant link between a certain lifestyle and brain tumors. The main cause is the fact that gliomas are not a common disease in the general population. This means that cohort studies cannot gather sufficient information, which in turn determines that data can only be collected from case-control studies (60).

Diet and eating habits have not yet been proven to exert any certain influence on the development of gliomas. A study by $\mathrm{Hu}$ and all, in a hospital based case-control showed a relation between certain foods and gliomas (61). Consumption of fresh vegetables and fruits was inversely associated with gliomas $(\mathrm{OR}=0.29)$. The same effect was found for fresh fish. The consumption of salted vegetables 
determines a high risk for brain tumors $(\mathrm{OR}=2.54)$. This is explained by the high content of N-nitroso compounds (NOC) and NOC precursors. The study value is limited, as it is a hospital-based case-control study of diet and by the low number of cases (73 glioma patients). A study conducted in California in 1997 among women with gliomas, also demonstrated a correlation between cured meat and an increased risk of gliomas, risk that was reduced by consumption of vegetables (62). Vegetable intake also decreased risk in another large cohort study (63).

Two recent studies have shown that high coffee and tea intake are inversely correlated with glioma risk $(64,65)$. The first one reflects data from three independent cohort studies. Tea (more than five cups a day) and coffee reduced the risk for glioma $(\mathrm{RR}=0.60,95 \%$ CI 0.41 $0.87)$. No association was found between decaffeinated coffee and risk of glioma, suggesting that caffeine has protective effects. In the second study, high coffee and tea intake $(>100 \mathrm{ml} /$ day $)$ were both associated with a significant lower risk for glial tumors.

Vitamin intake, especially vitamins A, D and $\mathrm{E}$ was correlated with a lower risk for gliomas, both in population and experimental studies. Both food and supplement vitamins had this effect $(61,62$, 66). Retinoids, compounds related to vitamin $A$, have a significant anti oncogenic effect (66). Alfacalcidol, a vitamin D analog also has anti proliferative effects on glioma cell cultures (67). Tocopherols (vitamin E) also exert anti oncogenic effects on glioma cells (66). Dietary minerals, especially calcium and zinc, have protective effects against tumors, including gliomas $(68,69)$. No correlation between acrylamide, present in several heat-prepared foods and glioma risk was found by a study (70).

Obesity and an increased body mass index (BMI) have been proven to be risk factors for gliomas in at least four studies (60). Obesity and it's direct consequences, hyperglycemia and type 2 diabetes mellitus, were also found to be independent risk factors for a poor outcome in patients with HGG (71,72) while an increased BMI didn't influence survival in another study (73).

Caloric restriction may have an important role in improving outcome for gliomas (74). This is based on the fact that while normal glial cells can adapt their metabolism, tumor cells cannot do the same. Dietary restriction reduced angiogenesis in a orthotopic mouse brain tumor model and also in human glioma cultures $(75,76)$. Also normal nervous cells can use ketone bodies for energy, while tumor cells are highly dependent on glycolysis (77). This is the rationale for using a high-fat, low-carbohydrate diet (ketogenic diet) as adjuvant therapy for gliomas (77). The ketogenic diet also enhanced the anti-tumor effect of radiation in a study (78). Caloric restriction with glucose withdrawal could cause phosphorylation of AMP-activated protein kinase (AMPK), and this may cause apoptosis in astrocytoma cells but not in normal cells under similar energy stress (79).

There is no certain evidence linking alcohol or smoking to an increased risk for gliomas. This is due to the small number of cases in different studies, the incomplete research hypothesis and deficitary patient selection (80). In the Melbourne Collaborative Cohort study, alcohol was associated with the risk for developing 
gliomas in a dose-response relation (81). But an older study from some of the members of the same team did not reveal any link between alcohol usage and gliomas (82). A study by DeVito and all, showed that ethanol inhibited the stimulation of ICAM-1 (an adhesion molecule) by TNF- $\alpha$ (83). ICAM-1 is an important molecule in the neuroimune response, and it's inhibition by ethanol, could explain a lower response of the CNS to injury, including gliomas (83).

In a cohort study, Efird and his team found an increased risk for gliomas in smokers, marijuana consumers, and coffee drinkers ( $>7$ cups/day) (84). A study on a population of 22.946 icelanders, also found smoking as a risk factor of cancer for all sites, except endometrium (85). Multiple studies did not find any relation between smoking and glioma risk (82, 86-88), while others have mixed conclusions (89). Alcohol and cigarette smoking are not currently considered to be risk factors for malignant brain tumors (90). A review of studies concerning marijuana smoking and risk for cancer did not find any increase in the risk for gliomas (91), but some studies support the hypothesis of cannabinoids as an effective adjuvant therapy $(92,93)$.

\section{Allergies, atopic conditions, infections, other disease, medication}

Allergies have clearly been indicated by most studies regarding this subject, as protective conditions against gliomas (94101). In a meta-analysis published in 2011, by Chen and coworkers, that included 12 studies, authors conclude that allergies could significantly decrease the risk of gliomas (102). Moreover, some studies have shown that, the number of allergies for a patient is directly proportional with a smaller risk $(98,101)$. In a study risk decreased with $31-45 \%$ for every new atopic condition (98). Antihistamine usage was not correlated with this risk (101). In most studies the levels of IgE, an objective assessment tool for allergic conditions, correlated with the risk for glioma. The risk increased inversely with the levels of $\operatorname{IgE}$ (100, 103-105). It seems that function of immune cells is altered in patients with GBM, in the sense that instead of preventing tumor appearance, immunity mechanisms support it (106). sCD23, a soluble marker, part of the humoral immune system, that enhances inflammatory response, is lower in GBM patients than controls (107). sDC14 that inhibits inflammatory response, is higher in GBM group vs. controls (107). Two subtypes of Interleukin (IL)-4 and IL-3 were also associated with GBM, and OR for GBM were opposite of the ones for asthma (108). In a study, GBM patients having high levels of $\mathrm{IgE}$ survived 9 month longer, than those with normal levels (109). Autoimmune disease were also inversely correlated with GBM, in one study $(\mathrm{OR}=0.49,95 \% \mathrm{CI}=0.35-0.69)$, the most significant being diabetes (96). Another study showed that patients reporting a previous infectious disease had a RR of $0.72,95 \%$ CI $0.61-0.85$ of developing GBM (95).

Until now some viruses of the Polyoma family, like BK virus, simian vacuolating virus 40 (SV40) and especially JC virus (JCV), have been proven to have oncogenic effect for GBM in experimental conditions (110). JCV proved oncogenic effect for malignant brain tumors in test animals. IgG antibodies to the capsid of JCV, proved to increase OR for developing GBM to 1.46, $\mathrm{CI}=0.61-3.5$ in a group of patients (111). $\operatorname{IgG}$ for varicella zoster was inversely 
correlated with glioma and some studies reported multiple HCMV gene products in glial tumors when compared to normal tissue (5). VZV IgG levels were more common in glioma cases vs. controls in another study $(\mathrm{OR}=0.68,95 \% \mathrm{CI}=0.41$ 1.13)(112).

Another condition investigated for a possible connection with HGG was epilepsy. A study found a 6-fold increase of risk for glioma in patients suffering from epilepsy in the last 2 years prior to diagnostic (95). The risk was highest for epilepsy for 20 years or less prior to diagnostic, although epilepsy $>20$ years still had a higher risk. The Interphone Group also found a high risk of gliomas in patients with epileptic seizures (99). The authors conclude that seizures suggest a long preclinical evolution of gliomas, since they did not create two separate groups for low or high grade tumors.

A family history of cancer could be a risk factor for developing brain tumors. A study found that risk of gliomas increases 1.4-3.4 fold familial history is positive for stomach, colon, prostate or Hodgkin disease cancers (113). The authors found no connection between glioma risk and a family history of brain tumors. However a study from Sweden found an increased risk for gliomas for people who had a parent suffering from this disease (114). A family history of brain tumors also increased risk for oligodendrogliomas in a mixt ScandinavianUS pooled analysis of 7 case-control studies (115).

Non-steroidal anti-inflammatory drugs (NSAID) were correlated with a lower risk for developing GBM. In a study by SivakSears and all, GBM cases reported a smaller use of NSAIDS than controls (116). The findings were strongest for aspirin and ibuprofen. Another case-control study found a 33\% lower risk for GBM in those reporting a regular use of NSAID (117). The authors failed in showing which NSAID had this effect. The influence of NSAID on gliomas, could be explained by the fact that they inhibit prostaglandins, inflammation mediators, that have a potential oncogenic effect (116). Angiogenesis, a vital tumor growth process, is linked to cyclooxygenase-2 driven inflammation, and this enzyme is irreversibly blocked by aspirin for example (116).

TABLE II

Medical conditions and relation to glioma risk

\begin{tabular}{|l|l|c|}
\hline Condition & $\begin{array}{l}\text { Relation to } \\
\text { glioma risk }\end{array}$ & No. of ref. \\
\hline Allergies & Decreased risk & $94-101$ \\
\hline $\begin{array}{l}\text { Increased IgE } \\
\text { levels }\end{array}$ & Decreased risk & $100,103-105$ \\
\hline $\begin{array}{l}\text { Autoimmune } \\
\text { disease }\end{array}$ & Decreased risk & 96 \\
\hline $\begin{array}{l}\text { Polyoma virus } \\
\text { infections }\end{array}$ & $\begin{array}{l}\text { Increased risk } \\
\text { (experimenal) }\end{array}$ & 110 \\
\hline Epilepsy & Increased risk & 95,99 \\
\hline $\begin{array}{l}\text { NSAID } \\
\text { consumption }\end{array}$ & Decreased risk & 116,117 \\
\hline
\end{tabular}

\section{Occupation and environment factors}

Determining a relation between a certain occupation and the risk for brain tumors is difficult. In most professional areas, workers are exposed to more than one possible risk factor (3). It is hard to determine what is the total risk determined by all these factors together. For example, even if a certain chemical is proven to be an oncogenic agent, it's interaction with other elements, could increase or decrease risk (3). Moreover, chemicals that have been proven to favor tumor genesis, had that effect on lab animals, where they were directly implanted. Their effect through another type of contact (touching, 
inhalation) could be different (3). All these things make it difficult to link certain professional factors with the risk of brain tumors.

A case-control study from Germany, did not find any association between a certain occupational field and the risk for developing gliomas. Authors studied six occupational sectors -chemical, agricultural, transport, electric/electronic, construction, metal- but found no significant risk in any profession (118). In the San Francisco Bay Area, physicians, surgeons, artists, foundry and smelter workers and petroleum and gas workers were at a higher risk for gliomas (119). A possible explanation is that health practitioners have raised access to diagnostic procedures that could explain some of the higher incidence (119). This is no longer a plausible factor because the access and quality of diagnostic procedures have increased dramatically. Also, medical staff has contact with a large number of agents, i.e. disinfectants, biological agents, radiation, that could lead to an increased risk (119). Parental work in agriculture, motor-vehicle related, electric domain determined an increased incidence in children in another study (120). This association was valid for both parents, while work in the textile industry was true only for mothers. A retrospective research found a positive association between children gliomas and father exposure to lead, cleaning solvents, pesticides from lawn care, during pregnancy period or immediately after birth (121). It must be noted that this study only took into consideration exposure resulting from hobbies, not occupational.

Exposure to pesticides was largely investigated as a risk factor for cancers. Phenoxy herbicides were proven as a cause for malignant lymphoma and soft-tissue sarcoma (122). A hospital-based, casecontrol study did not prove any association between insecticides or herbicides and gliomas, although women exposed to herbicides were at a much larger risk of developing meningiomas than those that were not exposed to these substances (123). Opposite results were obtained in a retrospective study from India, which showed that gliomas were much more frequent in orchard workers, residents or children playing in orchards that were exposed to numerous chemicals (chlorpyriphos, dimethoate, mancozeb and captan) for more than 10 years (124). A study of residents of rural zones from several US regions also proved that not washing or changing clothes immediately after applying pesticides constitutes a risk factor for developing gliomas (125). Occupational exposure did not increase rsik of gliomas instead it determined a higher risk of meningiomas (126). A study noted a higher incidence of gliomas in professionals of the following domains: IT, farm workers, financial, medicine, management, while it found a decreased incidence in childcare workers (127). A possible link between gliomas and physiological stress was also investigated, and found that major life events in a 5 years period prior to diagnostic, constituted a risk factor (128). Studies trying to find a connection between sociodemographic variables and gliomas found mixed or inconclusive results (129).

\section{Head trauma}

An association between trauma and brain tumors has not yet been clearly demonstrated. Although that there are some reports of a positive association, the relation is either non-significant or inconsistent (4). Associations have been made between perinatal or adult head trauma or combined 
perinatal and adult head trauma (4). In a study OR for gliomas following any head injury was only 1.2 (95\% CI 0.9-1.5) in men, and lower for females (130). In a Danish cohort study, that included patients hospitalized for concussion, fractured skull or any other head trauma, the incidence of gliomas was the same as for the general population (131). Several authors reported cases that indicated head trauma as the cause of gliomas and its influence needs to be further investigated (132).

\section{Other suspected risk factors}

There have been several sporadic studies investigating potential risk factors for gliomas. Use of hair dye could increase the risk of bladder and hematopoietic cancers, but no association was found with glioma (133). High birth weight $(>4000 \mathrm{~g})$ was associated with an increased risk for astrocytoma, and this risk was 19\% higher for every $1000 \mathrm{~g}$ (134). Birth anomalies or season of birth were not associated with an increased risk for glial tumors (135).

\section{References}

1.CBTRUS (Central Brain Tumor Registry of the United States) (2012). Statistical Report: Primary Brain and Central Nervous System Tumors Diagnosed in the United States in 2004-2008. Central Brain Tumor Registry of the United States.

2. Ferlay J, Shin HR, Bray F, Forman D, Mathers C, Parkin DM. Estimates of worldwide burden of cancer in 2008: GLOBOCAN 2008. Int J Cancer. 2010 Dec 15;127(12):2893-917.doi:10.1002/ijc.25516.

3.Wrensch M, Minn Y, Chew T, Bondy M, Berger MS. Epidemiology of primary brain tumors: current concepts and review of the literature. Neuro Oncol. 2002 Oct;4(4):278-99.

4.Ohgaki H, Kleihues P. Epidemiology and etiology of gliomas. Acta Neuropathol. 2005 Jan;109(1):93-108.

5.Bondy ML, Scheurer ME, Malmer B, BarnholtzSloan JS, Davis FG, Il'yasova D, Kruchko C, McCarthy BJ, Rajaraman P, Schwartzbaum JA, Sadetzki S, Schlehofer B, Tihan T, Wiemels JL, Wrensch M, Buffler PA; Brain Tumor Epidemiology Consortium. Brain tumor epidemiology: consensus from the Brain
Tumor Epidemiology Consortium. Cancer. 2008 Oct 1;113(7 Suppl):1953-68

6.Iwamoto FM, Cooper AR, Reiner AS, Nayak L, Abrey LE. Glioblastoma in the elderly: the Memorial SloanKettering Cancer Center Experience (1997-2007). Cancer. 2009 Aug 15;115(16):3758-66.

7.Verger E, Valduvieco I, Caral L, Pujol T, Ribalta T, Viñolas N, Boget T, Oleaga L, Blanco Y, Graus F. Does gender matter in glioblastoma? Clin Transl Oncol. 2011 Oct;13(10):737-41.

8.Kabat GC, Etgen AM, Rohan TE. Do steroid hormones play a role in the etiology of glioma? Cancer Epidemiol Biomarkers Prev. 2010 Oct;19(10):2421-7.

9.Cowppli-Bony A, Bouvier G, Rué M, Loiseau H, Vital A, Lebailly P, Fabbro-Peray P, Baldi I. Brain tumors and hormonal factors: review of the epidemiological literature. Cancer Causes Control. 2011 May;22(5):697-714.

10.Michaud DS, Gallo V, Schlehofer B, Tjønneland A, Olsen A, Overvad K, Dahm CC, Kaaks R, Lukanova A, Boeing H, Schütze M, Trichopoulou A, Bamia C, Kyrozis A, Sacerdote C, Agnoli C, Palli D, Tumino R, Mattiello A, Bueno-de-Mesquita HB, Ros MM, Peeters $\mathrm{PH}$, van Gils $\mathrm{CH}$, Lund E, Bakken K, Gram IT, Barricarte A, Navarro C, Dorronsoro M, Sánchez MJ, Rodríguez L, Duell EJ, Hallmans G, Melin BS, Manjer J, Borgquist S, Khaw KT, Wareham N, Allen NE, Tsilidis KK, Romieu I, Rinaldi S, Vineis P, Riboli E. Reproductive factors and exogenous hormone use in relation to risk of glioma and meningioma in a large European cohort study. Cancer Epidemiol Biomarkers Prev. 2010 Oct;19(10):2562-9.

11.Kabat GC, Park Y, Hollenbeck AR, Schatzkin A, Rohan TE. Reproductive factors and exogenous hormone use and risk of adult glioma in women in the NIH-AARP Diet and Health Study. Int J Cancer. 2011 Feb 15;128(4):944-50.

12.Wigertz A, Lönn S, Hall P, Auvinen A, Christensen HC, Johansen C, Klaeboe L, Salminen T, Schoemaker MJ, Swerdlow AJ, Tynes T, Feychting M. Reproductive factors and risk of meningioma and glioma. Cancer Epidemiol Biomarkers Prev. 2008 Oct;17(10):2663-70. 13.Benson VS, Pirie K, Green J, Bull D, Casabonne D, Reeves GK, Beral V; Million Women Study Collaborators. Hormone replacement therapy and incidence of central nervous system tumours in the Million Women Study. Int J Cancer. 2010 Oct 1;127(7):1692-8.

14.Wigertz A, Lönn S, Mathiesen T, Ahlbom A, Hall P, Feychting M; Swedish Interphone Study Group. Risk of brain tumors associated with exposure to exogenous female sex hormones. Am J Epidemiol. 2006 Oct $1 ; 164(7): 629-36$

15. Wrensch M, Lee M, Miike R, Newman B, Barger G, Davis R, Wiencke J, Neuhaus J. Familial and personal 
medical history of cancer and nervous system conditions among adults with glioma and controls. Am J Epidemiol. 1997 Apr 1;145(7):581-93.

16.Malmer B, Grönberg H, Bergenheim AT, Lenner P, Henriksson R. Familial aggregation of astrocytoma in northern Sweden: an epidemiological cohort study. Int J Cancer. 1999 May 5;81(3):366-70.

17.Malmer B, Henriksson R, Grönberg H. Familial brain tumours-genetics or environment? A nationwide cohort study of cancer risk in spouses and first-degree relatives of brain tumour patients. Int J Cancer. 2003 Aug 20;106(2):260-3.

18. Malmer B, Iselius L, Holmberg E, Collins A, Henriksson R, Grönberg H. Genetic epidemiology of glioma. Br J Cancer. 2001 Feb 2;84(3):429-34.

19.Malmer B, Haraldsson S, Einarsdottir E, Lindgren P, Holmberg D. Homozygosity mapping of familial glioma in Northern Sweden. Acta Oncol. 2005;44(2):114-9.

20.O'Neill BP, Blondal H, Yang P, Olafsdottir GH, Sigvaldason H, Jenkins RB, Kimmel DW, Scheithauer BW, Rocca WA, Bjornsson J, Tulinius H. Risk of cancer among relatives of patients with glioma. Cancer Epidemiol Biomarkers Prev. 2002 Sep;11(9):921-4.

21. Olivier M, Goldgar DE, Sodha N, Ohgaki H, Kleihues P, Hainaut P, Eeles RA. Li-Fraumeni and related syndromes: correlation between tumor type, family structure, and TP53 genotype. Cancer Res. 2003 Oct 15;63(20):6643-50.

22.Paunu N, Syrjäkoski K, Sankila R, Simola KO, Helén P, Niemelä M, Matikainen M, Isola J, Haapasalo H. Analysis of p53 tumor suppressor gene in families with multiple glioma patients. J Neurooncol. 2001 Dec;55(3):159-65.

23.Jasperson KW, Burt RW. APC-Associated Polyposis Conditions. 1998 Dec 18 (updated 2011 Oct 27). In: Pagon RA, Bird TD, Dolan CR, Stephens K, Adam MP, editors. GeneReviews ${ }^{\mathrm{TM}}$ (Internet). Seattle (WA): University of Washington, Seattle; 1993-. Available From

http://www.ncbi.nlm.nih.gov/books/NBK1345/PubMed PMID: 20301519

24.Hegi ME, Diserens AC, Gorlia T, Hamou MF, de Tribolet N, Weller M, Kros JM, Hainfellner JA, Mason W, Mariani L, Bromberg JE, Hau P, Mirimanoff RO, Cairncross JG, Janzer RC, Stupp R. MGMT gene silencing and benefit from temozolomide in glioblastoma. N Engl J Med. 2005 Mar 10;352(10):9971003.

25.Hegi ME, Diserens AC, Godard S, Dietrich PY, Regli L, Ostermann S, Otten P, Van Melle G, de Tribolet N, Stupp R. Clinical trial substantiates the predictive value of O-6-methylguanine-DNA methyltransferase promoter methylation in glioblastoma patients treated with temozolomide. Clin Cancer Res.
2004 Mar 15;10(6):1871-4.

26.Lakomy R, Sana J, Hankeova S, Fadrus P, Kren L, Lzicarova E, Svoboda M, Dolezelova H, Smrcka M, Vyzula R, Michalek J, Hajduch M, Slaby O. MiR-195, miR-196b, miR-181c, miR-21 expression levels and O6-methylguanine-DNA methyltransferase methylation status are associated with clinical outcome in glioblastoma patients. Cancer Sci. 2011 Dec;102(12):2186-90.

27.Liu Y, Scheurer ME, El-Zein R, Cao Y, Do KA, Gilbert M, Aldape KD, Wei Q, Etzel C, Bondy ML. Association and interactions between DNA repair gene polymorphisms and adult glioma. Cancer Epidemiol Biomarkers Prev. 2009 Jan;18(1):204-14.

28.Zhou K, Hu D, Lu J, Fan W, Liu H, Chen H, Chen G, Wei Q, Du G, Mao Y, Lu D, Zhou L. A genetic variant in the APE1/Ref-1 gene promoter $-141 \mathrm{~T} / \mathrm{G}$ may modulate risk of glioblastoma in a Chinese Han population. BMC Cancer. 2011 Mar 23;11:104.

29.Bethke L, Webb E, Murray A, Schoemaker M, Johansen C, Christensen HC, Muir K, McKinney P, Hepworth S, Dimitropoulou P, Lophatananon A, Feychting M, Lönn S, Ahlbom A, Malmer B, Henriksson R, Auvinen A, Kiuru A, Salminen T, Swerdlow A, Houlston R. Comprehensive analysis of the role of DNA repair gene polymorphisms on risk of glioma. Hum Mol Genet. 2008 Mar 15;17(6):800-5.

30.Chen P, Wiencke J, Aldape K, Kesler-Diaz A, Miike R, Kelsey K, Lee M, Liu J, Wrensch M. Association of an ERCC1 polymorphism with adult-onset glioma. Cancer Epidemiol Biomarkers Prev. 2000 Aug;9(8):8437.

31.Wrensch M, Kelsey KT, Liu M, Miike R, Moghadassi M, Sison JD, Aldape K, McMillan A, Wiemels J, Wiencke JK. ERCC1 and ERCC2 polymorphisms and adult glioma. Neuro Oncol. 2005 Oct;7(4):495-507.

32.Chen H, Wang W, Xingjie Z, Song X, Fan W, Keke Z, Chen G, Zhao Y, Mao Y, Lu D. Association between genetic variations of vascular endothelial growth factor receptor 2 and glioma in the chinese han population. J Mol Neurosci. 2012 Jul;47(3):448-57. Epub 2012 Jan 25.

33.Wang SS, Hartge P, Yeager M, Carreón T, Ruder AM, Linet M, Inskip PD, Black A, Hsing AW, Alavanja $M$, Beane-Freeman L, Safaiean $M$, Chanock SJ, Rajaraman P. Joint associations between genetic variants and reproductive factors in glioma risk among women. Am J Epidemiol. 2011 Oct 15;174(8):901-8.

34.de Tayrac M, Aubry M, Saïkali S, Etcheverry A, Surbled C, Guénot F, Galibert MD, Hamlat A, Lesimple T, Quillien V, Menei P, Mosser J. A 4-gene signature associated with clinical outcome in high-grade gliomas. Clin Cancer Res. 2011 Jan 15;17(2):317-27. 35.Egan KM, Thompson RC, Nabors LB, Olson JJ, 
Brat DJ, Larocca RV, Brem S, Moots PL, Madden MH, Browning JE, Ann Chen Y. Cancer susceptibility variants and the risk of adult glioma in a US casecontrol study. J Neurooncol. 2011 Sep;104(2):535-42. Epub 2011 Jan 4. Erratum in: J Neurooncol. 2011 Sep;104(2):543.

36.Shintani T, Hayakawa N, Hoshi M, Sumida M, Kurisu K, Oki S, Kodama Y, Kajikawa H, Inai K, Kamada N. High incidence of meningioma among Hiroshima atomic bomb survivors. J Radiat Res. 1999 Mar;40(1):49-57.

37.Blettner M, Schlehofer B, Samkange-Zeeb F, Berg G, Schlaefer K, Schüz J. Medical exposure to ionising radiation and the risk of brain tumours: Interphone study group, Germany. Eur J Cancer. 2007 Sep;43(13):1990-8.

38.Davis F, Il'yasova D, Rankin K, McCarthy B, Bigner DD. Medical diagnostic radiation exposures and risk of gliomas. Radiat Res. 2011 Jun;175(6):790-6.

39.INTERPHONE Study Group. Brain tumour risk in relation to mobile telephone use: results of the INTERPHONE international case-control study. Int J Epidemiol. 2010 Jun;39(3):675-94. Epub 2010 May 17. Erratum in: Int J Epidemiol. 2012 Feb;41(1):328.

40.Hardell L, Carlberg M, Hansson Mild K. Re-analysis of risk for glioma in relation to mobile telephone use: comparison with the results of the Interphone international case-control study. Int J Epidemiol. 2011 Aug;40(4):1126-8.

41.Lönn S, Ahlbom A, Hall P, Feychting M; Swedish Interphone Study Group. Long-term mobile phone use and brain tumor risk. Am J Epidemiol. 2005 Mar 15;161(6):526-35.

42.Morgan L. Re: "Long-term mobile phone use and brain tumor risk". Am J Epidemiol. 2005 Sep 15;162(6):599-600; author reply 601.

43.Milham S. Re: "Long-term mobile phone use and brain tumor risk". Am J Epidemiol. 2005 Sep 15;162(6):599; author reply 601.

44.Hardell L, Mild KH, Kundi M. Re: "Long-term mobile phone use and brain tumor risk". Am J Epidemiol. 2005 Sep 15;162(6):600-1; author reply 601. 45.Hardell L, Carlberg M, Hansson Mild K. Pooled analysis of case-control studies on malignant brain tumours and the use of mobile and cordless phones including living and deceased subjects. Int $\mathrm{J}$ Oncol. 2011 May;38(5):1465-74

46.Hardell L, Carlberg M, Hansson Mild K. Mobile phone use and the risk for malignant brain tumors: a case-control study on deceased cases and controls. Neuroepidemiology. 2010 Aug;35(2):109-14

47.Hardell L, Carlberg M. Mobile phones, cordless phones and the risk for brain tumours. Int J Oncol. 2009 Jul;35(1):5-17.

48.Hardell L, Carlberg M, Hansson Mild K.
Epidemiological evidence for an association between use of wireless phones and tumor diseases. Pathophysiology. 2009 Aug;16(2-3):113-22.

49.Hardell L, Carlberg M, Söderqvist F, Mild KH, Morgan LL. Long-term use of cellular phones and brain tumours: increased risk associated with use for $>$ or $=10$ years. Occup Environ Med. 2007 Sep;64(9):62632.

50.Cardis E, Armstrong BK, Bowman JD, Giles GG, Hours M, Krewski D, McBride M, Parent ME, Sadetzki S, Woodward A, Brown J, Chetrit A, Figuerola J, Hoffmann C, Jarus-Hakak A, Montestruq L, Nadon L, Richardson L, Villegas R, Vrijheid M. Risk of brain tumours in relation to estimated RF dose from mobile phones: results from five Interphone countries. Occup Environ Med. 2011 Sep;68(9):631-40

51.Frei P, Poulsen AH, Johansen C, Olsen JH, StedingJessen M, Schüz J. Use of mobile phones and risk of brain tumours: update of Danish cohort study. BMJ. 2011 Oct 19;343:d6387 52.Schüz J, Jacobsen R, Olsen JH, Boice JD Jr, McLaughlin JK, Johansen C. Cellular telephone use and cancer risk: update of a nationwide Danish cohort. J Natl Cancer Inst. 2006 Dec 6;98(23):1707-13

53.Johansen C, Boice J Jr, McLaughlin J, Olsen J. Cellular telephones and cancer--a nationwide cohort study in Denmark. J Natl Cancer Inst. 2001 Feb 7;93(3):203-7.

54.Hocking B. Re: cellular telephones and cancer--a nationwide cohort study in Denmark. J Natl Cancer Inst. 2001 Jun 6;93(11):877-8; author reply 878-9.

55.Godward S, Sandhu M, Skinner J, McCann J. Re: cellular telephones and cancer--a nationwide cohort study in Denmark. J Natl Cancer Inst. 2001 Jun 6;93(11):878; author reply 878-9.

56.Hardell L, Mild KH. Re: Cellular telephones and cancer--a nationwide cohort study in Denmark. J Natl Cancer Inst. 2001 Jun 20;93(12):952-3.

57.Baan R, Grosse Y, Lauby-Secretan B, El Ghissassi F, Bouvard V, Benbrahim-Tallaa L, Guha N, Islami F, Galichet L, Straif K; WHO International Agency for Research on Cancer Monograph Working Group. Carcinogenicity of radiofrequency electromagnetic fields. Lancet Oncol. 2011 Jul;12(7):624-6.

58.Little MP, Rajaraman P, Curtis RE, Devesa SS, Inskip PD, Check DP, Linet MS. Mobile phone use and glioma risk: comparison of epidemiological study results with incidence trends in the United States. BMJ. 2012 Mar 8;344:e1147.

59.Kundi M. The controversy about a possible relationship between mobile phone use and cancer. Environ Health Perspect. 2009 Mar;117(3):316-24

60.Benson VS, Pirie K, Green J, Casabonne D, Beral V; Million Women Study Collaborators. Lifestyle factors and primary glioma and meningioma tumours in the 
Million Women Study cohort. Br J Cancer. 2008 Jul 8;99(1):185-90.

61.Hu J, La Vecchia C, Negri E, Chatenoud L, Bosetti C, Jia X, Liu R, Huang G, Bi D, Wang C. Diet and brain cancer in adults: a case-control study in northeast China. Int J Cancer. 1999 Mar 31;81(1):20-3.

62.Blowers L, Preston-Martin S, Mack WJ. Dietary and other lifestyle factors of women with brain gliomas in Los Angeles County (California, USA). Cancer Causes Control. 1997 Jan;8(1):5-12.

63.Terry MB, Howe G, Pogoda JM, Zhang FF, Ahlbom A, Choi W, Giles GG, Little J, Lubin F, Menegoz F, Ryan P, Schlehofer B, Preston-Martin S. An international case-control study of adult diet and brain tumor risk: a histology-specific analysis by food group. Ann Epidemiol. 2009 Mar;19(3):161-71.

64.Holick CN, Smith SG, Giovannucci E, Michaud DS. Coffee, tea, caffeine intake, and risk of adult glioma in three prospective cohort studies. Cancer Epidemiol Biomarkers Prev. 2010 Jan;19(1):39-47.

65.Michaud DS, Gallo V, Schlehofer B, Tjønneland A, Olsen A, Overvad K, Dahm CC, Teucher B, Lukanova A, Boeing H, Schütze M, Trichopoulou A, Lagiou P, Kyrozis A, Sacerdote C, Krogh V, Masala G, Tumino R, Mattiello A, Bueno-de-Mesquita HB, Ros MM, Peeters $\mathrm{PH}$, van Gils CH, Skeie G, Engeset D, Parr CL, Ardanaz E, Chirlaque MD, Dorronsoro M, Sánchez MJ, Argüelles M, Jakszyn P, Nilsson LM, Melin BS, Manjer J, Wirfält E, Khaw KT, Wareham N, Allen NE, Key TJ, Romieu I, Vineis P, Riboli E. Coffee and tea intake and risk of brain tumors in the European Prospective Investigation into Cancer and Nutrition (EPIC) cohort study. Am J Clin Nutr. 2010 Nov;92(5):1145-50.

66.Kyritsis AP, Bondy ML, Levin VA. Modulation of glioma risk and progression by dietary nutrients and antiinflammatory agents. Nutr Cancer. 2011;63(2):17484. Review.

67. Trouillas P, Honnorat J, Bret P, Jouvet A, Gerard JP. Redifferentiation therapy in brain tumors: long-lasting complete regression of glioblastomas and an anaplastic astrocytoma under long term 1-alphahydroxycholecalciferol. J Neurooncol. 2001 Jan;51(1):57-66.

68.Tedeschi-Blok N, Schwartzbaum J, Lee M, Miike R, Wrensch M; San Francisco Bay Area Adult Glioma Study. Dietary calcium consumption and astrocytic glioma: the San Francisco Bay Area Adult Glioma Study, 1991-1995. Nutr Cancer. 2001;39(2):196-203 69.Franklin RB, Costello LC. The important role of the apoptotic effects of zinc in the development of cancers. J Cell Biochem. 2009 Apr 1;106(5):750-7. Review.

70.Hogervorst JG, Schouten LJ, Konings EJ, Goldbohm RA, van den Brandt PA. Dietary acrylamide intake and brain cancer risk. Cancer Epidemiol Biomarkers Prev.
2009 May;18(5):1663-6

71.Chambless LB, Parker SL, Hassam-Malani L, McGirt MJ, Thompson RC. Type 2 diabetes mellitus and obesity are independent risk factors for poor outcome in patients with high-grade glioma. J Neurooncol. 2012 Jan;106(2):383-9.

72.Derr RL, Ye X, Islas MU, Desideri S, Saudek CD, Grossman SA. Association between hyperglycemia and survival in patients with newly diagnosed glioblastoma. J Clin Oncol. 2009 Mar 1;27(7):1082-6.

73.Jones LW, Ali-Osman F, Lipp E, Marcello JE, McCarthy B, McCoy L, Rice T, Wrensch M, Il'yasova D. Association between body mass index and mortality in patients with glioblastoma mutliforme. Cancer Causes Control. 2010 Dec;21(12):2195-201.

74.Seyfried BT, Kiebish M, Marsh J, Mukherjee P. Targeting energy metabolism in brain cancer through calorie restriction and the ketogenic diet. J Cancer Res Ther. 2009 Sep;5 Suppl 1:S7-15. Review

75.Mukherjee P, El-Abbadi MM, Kasperzyk JL, Ranes MK, Seyfried TN. Dietary restriction reduces angiogenesis and growth in an orthotopic mouse brain tumour model. Br J Cancer. 2002 May 20;86(10):161521.

76.Mukherjee P, Abate LE, Seyfried TN. Antiangiogenic and proapoptotic effects of dietary restriction on experimental mouse and human brain tumors. Clin Cancer Res. 2004 Aug 15;10(16):5622-9. 77.Maurer GD, Brucker DP, Bähr O, Harter PN, Hattingen E, Walenta S, Mueller-Klieser W, Steinbach JP, Rieger J. Differential utilization of ketone bodies by neurons and glioma cell lines: a rationale for ketogenic diet as experimental glioma therapy. BMC Cancer. 2011 Jul 26;11:315.

78.Abdelwahab MG, Fenton KE, Preul MC, Rho JM, Lynch A, Stafford P, Scheck AC. The ketogenic diet is an effective adjuvant to radiation therapy for the treatment of malignant glioma. PLoS One. 2012;7(5):e36197

79.Mukherjee P, Mulrooney TJ, Marsh J, Blair D, Chiles TC, Seyfried TN. Differential effects of energy stress on AMPK phosphorylation and apoptosis in experimental brain tumor and normal brain. Mol Cancer. 2008 May 12;7:37.

80.Fisher JL, Schwartzbaum JA, Wrensch M, Wiemels JL. Epidemiology of brain tumors. Neurol Clin. 2007 Nov;25(4):867-90, vii. Review. PubMed PMID: 17964019.

81.Baglietto L, Giles GG, English DR, Karahalios A, Hopper JL, Severi G. Alcohol consumption and risk of glioblastoma; evidence from the Melbourne Collaborative Cohort Study. Int J Cancer. 2011 Apr 15;128(8):1929-34.

82.Hurley SF, McNeil JJ, Donnan GA, Forbes A, Salzberg M, Giles GG. Tobacco smoking and alcohol 
consumption as risk factors for glioma: a case-control study in Melbourne, Australia. J Epidemiol Community Health. 1996 Aug;50(4):442-6.

83.DeVito WJ, Stone S, Mori K, Shamgochian M. Ethanol inhibits prolactin- and tumor necrosis factoralpha-, but not gamma interferon-induced expression of intercellular adhesion molecule-1 in human astrocytoma cells. J Cell Biochem. 2000 Apr;77(3):45564.

84.Efird JT, Friedman GD, Sidney S, Klatsky A, Habel LA, Udaltsova NV, Van den Eeden S, Nelson LM. The risk for malignant primary adult-onset glioma in a large, multiethnic, managed-care cohort: cigarette smoking and other lifestyle behaviors. J Neurooncol. 2004 May;68(1):57-69.

85.Tulinius $H$, Sigfússon $N$, Sigvaldason $H$, Bjarnadóttir K, Tryggvadóttir L. Risk factors for malignant diseases: a cohort study on a population of 22,946 Icelanders. Cancer Epidemiol Biomarkers Prev. 1997 Nov;6(11):863-73.

86.Holick CN, Giovannucci EL, Rosner B, Stampfer MJ, Michaud DS. Prospective study of cigarette smoking and adult glioma: dosage, duration, and latency. Neuro Oncol. 2007 Jul;9(3):326-34.

87.Lachance DH, Yang P, Johnson DR, Decker PA, Kollmeyer TM, McCoy LS, Rice T, Xiao Y, Ali-Osman F, Wang F, Stoddard SM, Sprau DJ, Kosel ML, Wiencke JK, Wiemels JL, Patoka JS, Davis F, McCarthy B, Rynearson AL, Worra JB, Fridley BL, O'Neill BP, Buckner JC, Il'yasova D, Jenkins RB, Wrensch MR. Associations of high-grade glioma with glioma risk alleles and histories of allergy and smoking. Am J Epidemiol. 2011 Sep 1;174(5):574-81.

88.Mandelzweig L, Novikov I, Sadetzki S. Smoking and risk of glioma: a meta-analysis. Cancer Causes Control. 2009 Dec;20(10):1927-38.

89.Silvera SA, Miller AB, Rohan TE. Cigarette smoking and risk of glioma: a prospective cohort study. Int J Cancer. 2006 Apr 1;118(7):1848-51

90.Cogliano VJ, Baan R, Straif K, Grosse Y, LaubySecretan B, El Ghissassi F, Bouvard V, BenbrahimTallaa L, Guha N, Freeman C, Galichet L, Wild CP. Preventable exposures associated with human cancers. J Natl Cancer Inst. 2011 Dec 21;103(24):1827-39. Epub 2011 Dec 12. Review

91.Hashibe M, Straif K, Tashkin DP, Morgenstern H, Greenland S, Zhang ZF. Epidemiologic review of marijuana use and cancer risk. Alcohol. 2005 Apr;35(3):265-75. Review.

92.Torres S, Lorente $M$, Rodríguez-Fornés $F$, Hernández-Tiedra S, Salazar M, García-Taboada E, Barcia J, Guzmán M, Velasco G. A combined preclinical therapy of cannabinoids and temozolomide against glioma. Mol Cancer Ther. 2011 Jan;10(1):90-103 93.Foroughi M, Hendson G, Sargent MA, Steinbok P.
Spontaneous regression of septum pellucidum/forniceal pilocytic astrocytomas--possible role of Cannabis inhalation. Childs Nerv Syst. 2011 Apr;27(4):671-9. 94.Wiemels JL, Wiencke JK, Sison JD, Miike R, McMillan A, Wrensch M. History of allergies among adults with glioma and controls. Int J Cancer. 2002 Apr 1;98(4):609-15.

95.Schlehofer B, Blettner M, Preston-Martin S, Niehoff D, Wahrendorf J, Arslan A, Ahlbom A, Choi WN, Giles GG, Howe GR, Little J, Ménégoz F, Ryan P. Role of medical history in brain tumour development. Results from the international adult brain tumour study. Int J Cancer. 1999 Jul 19;82(2):155-60.

96.Brenner AV, Linet MS, Fine HA, Shapiro WR, Selker RG, Black PM, Inskip PD. History of allergies and autoimmune diseases and risk of brain tumors in adults. Int J Cancer. 2002 May 10;99(2):252-9.

97.Schwartzbaum J, Jonsson F, Ahlbom A, PrestonMartin S, Lönn S, Söderberg KC, Feychting M. Cohort studies of association between self-reported allergic conditions, immune-related diagnoses and glioma and meningioma risk. Int J Cancer. 2003 Sep 1;106(3):4238. Review.

98.Il'yasova D, McCarthy B, Marcello J, Schildkraut JM, Moorman PG, Krishnamachari B, Ali-Osman F, Bigner DD, Davis F. Association between glioma and history of allergies, asthma, and eczema: a case-control study with three groups of controls. Cancer Epidemiol Biomarkers Prev. 2009 Apr;18(4):1232-8.

99.Berg-Beckhoff G, Schüz J, Blettner M, Münster E, Schlaefer K, Wahrendorf J, Schlehofer B. History of allergic disease and epilepsy and risk of glioma and meningioma (INTERPHONE study group, Germany). Eur J Epidemiol. 2009;24(8):433-40.

100.Wiemels JL, Wilson D, Patil C, Patoka J, McCoy L, Rice T, Schwartzbaum J, Heimberger A, Sampson JH, Chang S, Prados M, Wiencke JK, Wrensch M. IgE, allergy, and risk of glioma: update from the San Francisco Bay Area Adult Glioma Study in the temozolomide era. Int J Cancer. 2009 Aug 1;125(3):680-7

101.McCarthy BJ, Rankin K, Il'yasova D, Erdal S, Vick N, Ali-Osman F, Bigner DD, Davis F. Assessment of type of allergy and antihistamine use in the development of glioma. Cancer Epidemiol Biomarkers Prev. 2011 Feb;20(2):370-8.

102.Chen C, Xu T, Chen J, Zhou J, Yan Y, Lu Y, Wu S. Allergy and risk of glioma: a meta-analysis. Eur J Neurol. 2011 Mar;18(3):387-95. doi: 10.1111/j.14681331.2010.03187.x. Epub 2010 Aug 16

103.Wiemels JL, Wiencke JK, Patoka J, Moghadassi M, Chew T, McMillan A, Miike R, Barger G, Wrensch M. Reduced immunoglobulin E and allergy among adults with glioma compared with controls. Cancer Res. 2004 Nov 15;64(22):8468-73. 
104.Calboli FC, Cox DG, Buring JE, Gaziano JM, Ma J, Stampfer M, Willett WC, Tworoger SS, Hunter DJ, Camargo CA Jr, Michaud DS. Prediagnostic plasma IgE levels and risk of adult glioma in four prospective cohort studies. J Natl Cancer Inst. 2011 Nov 2;103(21):1588-95.

105.Schlehofer B, Siegmund B, Linseisen J, Schüz J, Rohrmann S, Becker S, Michaud D, Melin B, Bas Bueno-de-Mesquita H, Peeters PH, Vineis P, Tjonneland A, Olsen A, Overvad K, Romieu I, Boeing $\mathrm{H}$, Aleksandrova K, Trichopoulou A, Bamia C, Lagiou P, Sacerdote C, Palli D, Panico S, Sieri S, Tumino R, Sanchez MJ, Rodriguez L, Dorronsoro M, Duell EJ, Chirlaque MD, Barricarte A, Borgquist S, Manjer J, Gallo V, Allen NE, Key TJ, Riboli E, Kaaks R, Wahrendorf J. Primary brain tumours and specific serum immunoglobulin E: a case-control study nested in the European Prospective Investigation into Cancer and Nutrition cohort. Allergy. 2011 Nov;66(11):143441.

106.Curran CS, Bertics PJ. Eosinophils in glioblastoma biology. J Neuroinflammation. 2012 Jan 17;9:11. Review.

107.Zhou M, Wiemels JL, Bracci PM, Wrensch MR, McCoy LS, Rice T, Sison JD, Patoka JS, Wiencke JK. Circulating levels of the innate and humoral immune regulators CD14 and CD23 are associated with adult glioma. Cancer Res. 2010 Oct 1;70(19):7534-42.

108.Schwartzbaum J, Ahlbom A, Malmer B, Lönn S, Brookes AJ, Doss H, Debinski W, Henriksson R, Feychting M. Polymorphisms associated with asthma are inversely related to glioblastoma multiforme. Cancer Res. 2005 Jul 15;65(14):6459-65.

109.Wrensch M, Wiencke JK, Wiemels J, Miike R, Patoka J, Moghadassi M, McMillan A, Kelsey KT, Aldape K, Lamborn KR, Parsa AT, Sison JD, Prados MD. Serum IgE, tumor epidermal growth factor receptor expression, and inherited polymorphisms associated with glioma survival. Cancer Res. 2006 Apr 15;66(8):4531-41.

110.White MK, Gordon J, Reiss K, Del Valle L, Croul S, Giordano A, Darbinyan A, Khalili K. Human polyomaviruses and brain tumors. Brain Res Brain Res Rev. 2005 Dec 1;50(1):69-85. Epub 2005 Jun 27. Review.

111.Rollison DE, Helzlsouer KJ, Alberg AJ, Hoffman S, Hou J, Daniel R, Shah KV, Major EO. Serum antibodies to JC virus, BK virus, simian virus 40 , and the risk of incident adult astrocytic brain tumors. Cancer Epidemiol Biomarkers Prev. 2003 May;12(5):460-3.

112.Sjöström S, Hjalmars U, Juto P, Wadell G, Hallmans G, Tjönneland A, Halkjaer J, Manjer J, Almquist M, Melin BS. Human immunoglobulin G levels of viruses and associated glioma risk. Cancer
Causes Control. 2011 Sep;22(9):1259-66.

113.Hill DA, Inskip PD, Shapiro WR, Selker RG, Fine HA, Black PM, Linet MS. Cancer in first-degree relatives and risk of glioma in adults. Cancer Epidemiol Biomarkers Prev. 2003 Dec;12(12):1443-8.

114.Hemminki K, Li X, Collins VP. Parental cancer as a risk factor for brain tumors (Sweden). Cancer Causes Control. 2001 Apr;12(3):195-9.

115.McCarthy BJ, Rankin KM, Aldape K, Bondy ML, Brännström T, Broholm H, Feychting M, Il'yasova D, Inskip PD, Johansen C, Melin BS, Ruder AM, Butler MA, Scheurer ME, Schüz J, Schwartzbaum JA, Wrensch MR, Davis FG. Risk factors for oligodendroglial tumors: a pooled international study. Neuro Oncol. 2011 Feb;13(2):242-50.

116.Sivak-Sears NR, Schwartzbaum JA, Miike R, Moghadassi M, Wrensch M. Case-control study of use of nonsteroidal antiinflammatory drugs and glioblastoma multiforme. Am J Epidemiol. 2004 Jun 15;159(12):1131-9.

117.Scheurer ME, El-Zein R, Thompson PA, Aldape KD, Levin VA, Gilbert MR, Weinberg JS, Bondy ML. Long-term anti-inflammatory and antihistamine medication use and adult glioma risk. Cancer Epidemiol Biomarkers Prev. 2008 May;17(5):1277-81. doi: 10.1158/1055-9965.EPI-07-2621

118.Samkange-Zeeb F, Schlehofer B, Schüz J, Schlaefer $\mathrm{K}$, Berg-Beckhoff G, Wahrendorf J, Blettner M. Occupation and risk of glioma, meningioma and acoustic neuroma: results from a German case-control study (interphone study group, Germany). Cancer Epidemiol. 2010 Feb;34(1):55-61.

119.Carozza SE, Wrensch M, Miike R, Newman B, Olshan AF, Savitz DA, Yost M, Lee M. Occupation and adult gliomas. Am J Epidemiol. 2000 Nov 1;152(9):83846.

120.Cordier S, Mandereau L, Preston-Martin S, Little J, Lubin F, Mueller B, Holly E, Filippini G, Peris-Bonet R, McCredie M, Choi NW, Arsla A. Parental occupations and childhood brain tumors: results of an international case-control study. Cancer Causes Control. 2001 Nov;12(9):865-74.

121.Rosso AL, Hovinga ME, Rorke-Adams LB, Spector LG, Bunin GR; Children's Oncology Group. A casecontrol study of childhood brain tumors and fathers' hobbies: a Children's Oncology Group study. Cancer Causes Control. 2008 Dec;19(10):1201-7.

122.Hardell L. Pesticides, soft-tissue sarcoma and nonHodgkin lymphoma--historical aspects on the precautionary principle in cancer prevention. Acta Oncol. 2008;47(3):347-54.

123.Samanic CM, De Roos AJ, Stewart PA, Rajaraman P, Waters MA, Inskip PD. Occupational exposure to pesticides and risk of adult brain tumors. Am J Epidemiol. 2008 Apr 15;167(8):976-85. 
124.Bhat AR, Wani MA, Kirmani AR. Brain cancer and pesticide relationship in orchard farmers of Kashmir. Indian J Occup Environ Med. 2010 Sep;14(3):78-86. 125.Ruder AM, Carreón T, Butler MA, Calvert GM, Davis-King KE, Waters MA, Schulte PA, Mandel JS, Morton RF, Reding DJ, Rosenman KD; Brain Cancer Collaborative Study Group. Exposure to farm crops, livestock, and farm tasks and risk of glioma: the Upper Midwest Health Study. Am J Epidemiol. 2009 Jun 15;169(12):1479-91.

126.Rajaraman P, Stewart PA, Samet JM, Schwartz BS, Linet MS, Zahm SH, Rothman N, Yeager M, Fine HA, Black PM, Loeffler J, Shapiro WR, Selker RG, Inskip PD. Lead, genetic susceptibility, and risk of adult brain tumors. Cancer Epidemiol Biomarkers Prev. 2006 Dec;15(12):2514-20.

127.De Roos AJ, Stewart PA, Linet MS, Heineman EF, Dosemeci M, Wilcosky T, Shapiro WR, Selker RG, Fine HA, Black PM, Inskip PD. Occupation and the risk of adult glioma in the United States. Cancer Causes Control. 2003 Mar;14(2):139-50.

128.Cabaniols C, Giorgi R, Chinot O, Ferahta N, Spinelli V, Alla P, Barrie M, Lehucher-Michel MP. Links between private habits, psychological stress and brain cancer: a case-control pilot study in France. J Neurooncol. 2011 Jun;103(2):307-16.

129.Inskip PD, Tarone RE, Hatch EE, Wilcosky TC, Fine HA, Black PM, Loeffler JS, Shapiro WR, Selker
RG, Linet MS. Sociodemographic indicators and risk of brain tumours. Int J Epidemiol. 2003 Apr;32(2):225-33. 130.Preston-Martin S, Pogoda JM, Schlehofer B, Blettner M, Howe GR, Ryan P, Menegoz F, Giles GG, Rodvall Y, Choi NW, Little J, Arslan A. An international case-control study of adult glioma and meningioma: the role of head trauma. Int J Epidemiol. 1998 Aug;27(4):579-86.

131.Inskip PD, Mellemkjaer L, Gridley G, Olsen JH. Incidence of intracranial tumors following hospitalization for head injuries (Denmark). Cancer Causes Control. 1998 Jan;9(1):109-16.

132.Zhou B, Liu W. Post-traumatic glioma: report of one case and review of the literature. Int J Med Sci. 2010 Jul 29;7(5):248-50. Review.

133.Bluhm EC, Zahm SH, Fine HA, Black PM, Loeffler JS, Shapiro WR, Selker RG, Inskip PD. Personal hair dye use and risks of glioma, meningioma, and acoustic neuroma among adults. Am J Epidemiol. 2007 Jan 1;165(1):63-71.

134.Harder T, Plagemann A, Harder A. Birth weight and subsequent risk of childhood primary brain tumors: a meta-analysis. Am J Epidemiol. 2008 Aug 15;168(4):366-73.

135.Efird JT. Season of birth and risk for adult onset glioma. Int J Environ Res Public Health. 2010 May;7(5):1913-36. 